\title{
Chitinophaga niabensis sp. nov. and Chitinophaga niastensis sp. nov., isolated from soil
}

\author{
Hang-Yeon Weon, ${ }^{1}$ Seung-Hee Yoo, ${ }^{2}$ Yoo-Jeong Kim, ${ }^{2}$ Jung-A Son, ${ }^{1}$ \\ Byung-Yong Kim, ${ }^{2}$ Soon-Wo Kwon ${ }^{2}$ and Bon-Sung Koo ${ }^{2}$
}

Correspondence

Soon-Wo Kwon

swkwon@rda.go.kr

\author{
${ }^{1}$ Applied Microbiology Division, National Institute of Agricultural Science and Technology, Rural \\ Development Administration, Suwon 441-707, Republic of Korea \\ ${ }^{2}$ Korean Agricultural Culture Collection (KACC), Microbial Genetics Division, National Institute of \\ Agricultural Biotechnology, Rural Development Administration, Suwon 441-707, Republic of Korea
}

Two yellow-coloured bacterial strains, designated JS $13-10^{\top}$ and $\mathrm{JS} 16-4^{\top}$, were isolated from soil from Jeju Island, Republic of Korea. On the basis of 16S rRNA gene sequence analysis, the strains were found to be affiliated with members of the genus Chitinophaga. Phenotypically, the novel strains were identified as being different from each other and from recognized species of the genus Chitinophaga. DNA-DNA hybridization tests between the two novel strains and closely related Chitinophaga reference strains produced DNA relatedness values that were significantly lower $(<36 \%)$ than those generally accepted as the highest threshold for the phylogenetic definition of a species. On the basis of their distinct taxonomic characteristics, these strains represent two novel species of the genus Chitinophaga, for which the names Chitinophaga niabensis sp. nov. (type strain $\mathrm{JS} 13-10^{\top}=\mathrm{KACC} 12952^{\top}=\mathrm{JCM} 15440^{\top}$ ) and Chitinophaga niastensis sp. nov. (type strain JS16-4 $4^{\top}=$ KACC $12954^{\top}=J C M 15441^{\top}$ ) are proposed.
The genus Chitinophaga was proposed by Sangkhobol \& Skerman (1981) for strains of filamentous, chitinolytic, gliding bacteria. Later, Cytophaga arvensicola, Flexibacter filiformis, Flexibacter japonensis and Flexibacter sancti were reclassified into the genus Chitinophaga, Chitinophaga skermanii was described (Kämpfer et al., 2006) and Chitinophaga arvensicola was redefined by Pankratov et al. (2006). Recently, Kim \& Jung (2007) described a novel strain $\left(\mathrm{KP} 01^{\mathrm{T}}\right)$ as also representing a novel species of the genus Chitinophaga and the name Chitinophaga terrae has been validly published. At the same time, two further strains, Gsoil 219 (=KACC 12833) and Gsoil 238 (=KACC 12832), were described by An et al. (2007) and proposed as 'Chitinophaga soli' and 'Chitinophaga terrae', respectively, but these names were not validly published. At the time of writing, there are nine species with validly published names in the genus Chitinophaga.

Soil samples were collected on Jeju Island, Republic of Korea. Soil ( $1 \mathrm{~g}$ ) was suspended in $9 \mathrm{ml} 0.85 \% \mathrm{NaCl}(\mathrm{w} / \mathrm{v})$ and mixed in a shaker for $30 \mathrm{~min}$. After serial dilution, aliquots of serial diluents were spread on R2A agar plates (Reasoner \& Geldreich, 1985) and incubated at $28{ }^{\circ} \mathrm{C}$ for 5 days. Two yellow-coloured isolates, designated strains JS13 $-10^{\mathrm{T}}$ and $\mathrm{JS} 16-4^{\mathrm{T}}$, were recovered. The following 11 Chitinophaga strains were used as reference strains in API

The GenBank/EMBL/DDBJ accession numbers for the 16S rRNA gene sequences of strains $\mathrm{JS} 13-10^{\top}$ and $\mathrm{JS} 16-4^{\top}$ are EU714259 and EU714260, respectively.
(bioMérieux) tests, DNA-DNA hybridizations and fatty acid analyses: Chitinophaga filiformis DSM $527^{\mathrm{T}}, C$. japonensis DSM $13484^{\mathrm{T}}$, C. pinensis DSM $2588^{\mathrm{T}}$ and $C$. sancti DSM $784^{\mathrm{T}}$ from the Deutsche Sammlung von Mikroorganismen und Zellkulturen (Braunschweig, Germany); C. ginsengisegetis KACC $12723^{\mathrm{T}}$, C. ginsengisoli KACC $12724^{\mathrm{T}}$, C. terrae KACC $12755^{\mathrm{T}}$ and strains KACC 12833 and KACC 12832 from the Korean Agricultural Culture Collection (Suwon, Republic of Korea); C. arvensicola KCTC $2943^{\mathrm{T}}$ from the Korean Collection for Type Cultures (Daejon, Republic of Korea) and $C$. skermanii CIP $109140^{\mathrm{T}}$ from the collection of the Pasteur Institute (Paris, France).

To investigate basic physiological and biochemical characteristics, the methods of Smibert \& Krieg (1994) were used to test for the following: Gram stain, catalase activity, oxidase activity and hydrolysis of casein, DNA, hypoxanthine, starch and xanthine. Carboxymethylcellulose (Sigma) $(0.1 \%)$ was used for the cellulase test. The hydrolysis of chitin [from crab shells $(1 \%, \mathrm{w} / \mathrm{v})$ ], pectin $(0.5 \%, \mathrm{w} / \mathrm{v})$ and tyrosine $(0.5 \%, \mathrm{w} / \mathrm{v})$ were also tested. To investigate cell morphology using transmission electron microscopy (model LEO 912AB; Zeiss) and phase-contrast microscopy (Axio; Zeiss), cells were grown on R2A agar (Difco). Temperature tolerance was tested by growing cells at $5,10,15,20,25,30,35,40$ and $45{ }^{\circ} \mathrm{C}$. Tolerance of different salinity levels was tested by growing cells in R2A broth (LAB) supplemented with $0,1,2,3$ and $5 \%(\mathrm{w} / \mathrm{v})$ 
$\mathrm{NaCl}$. The $\mathrm{pH}$ range $(\mathrm{pH} 4-10$, using increments of $1 \mathrm{pH}$ unit) for growth was determined in R2A broth buffered with citrate-phosphate or Tris/HCl buffers (Breznak \& Costilow, 1994). Tests with the commercial systems API 20NE, API ID 32GN and API ZYM (bioMérieux) were generally performed according to the manufacturer's instructions (in duplicate). The API ZYM tests were read after $4 \mathrm{~h}$ incubation at $37^{\circ} \mathrm{C}$ and the other API tests were read after 7 days at $28{ }^{\circ} \mathrm{C}$.

Genomic DNA was extracted using a DNeasy Tissue kit (Qiagen) by following the manufacturer's instructions. Sequencing of the 16S rRNA gene was performed as described by Kwon et al. (2003). Multiple alignments were performed using the CLUSTAL w program (Thompson et al., 1994). Evolutionary distances were calculated using the Kimura two-parameter model (Kimura, 1983). Phylogenetic trees were constructed with neighbour-joining (Saitou \& Nei, 1987) and maximum-parsimony methods (Fitch, 1971), using the MEGA3 program (Kumar et al., 2004), with bootstrap values based on 1000 replications (Felsenstein, 1985). The 16S rRNA gene sequences of strains JS13-10 ${ }^{\mathrm{T}}$ and JS16- $4^{\mathrm{T}}$ were based on a continuous stretch of $1402 \mathrm{bp}$.

DNA G + C contents were determined by means of HPLC analysis of deoxyribonucleosides, as described by Mesbah et al. (1989), using a reversed-phase column (Supelcosil LC$18 \mathrm{~S}$; Supelco). Isoprenoid quinones were analysed by using HPLC as described previously (Groth et al., 1996). After growth of the cells on R2A for 2 days at $28{ }^{\circ} \mathrm{C}$, fatty acid methyl esters were extracted and prepared using the standard protocol of the Microbial Identification System (MIDI; Microbial ID). DNA-DNA hybridization was carried out as described by Seldin \& Dubnau (1985). Probe labelling was conducted by using the non-radioactive DIG-High Prime DNA labelling and detection starter kit II (Roche Molecular Biochemicals). The hybridized DNA was visualized using a DIG luminescent detection kit (Roche).

Strains JS13-10 $0^{\mathrm{T}}$ and JS16-4 ${ }^{\mathrm{T}}$ were Gram-negative, aerobic, rod-shaped and catalase- and oxidase-positive. Strain JS13- $10^{\mathrm{T}}$ produced clear, round colonies whereas strain JS16-4 ${ }^{\mathrm{T}}$ produced smeared growth. The phenotypic characteristics of strains JS13-10 $10^{\mathrm{T}}$ and JS16-4 $4^{\mathrm{T}}$ are summarized and compared with those of type or reference strains from the genus Chitinophaga in Table 1.

Phylogenetically, strains JS13 $-10^{\mathrm{T}}$ and JS16- $4^{\mathrm{T}}$ were found to be members of the genus Chitinophaga (Fig. 1). The $16 \mathrm{~S}$ rRNA gene sequence similarity between strains JS13-10 and JS16-4 $4^{\mathrm{T}}$ was $94.6 \%$. Strain JS13 $-10^{\mathrm{T}}$ showed sequence similarities in the range 91.3-98.1\% with reference strains of the genus Chitinophaga, revealing a high level $(>97 \%)$ of sequence similarity ( $98.1 \%$ ) with ' $C$. soli' Gsoil 219 . Strain JS16- $4^{\mathrm{T}}$ showed sequence similarities of $92.4-98.1 \%$ with the reference strains of the genus Chitinophaga, having a high level $(>97 \%)$ of sequence similarity $(98.1 \%)$ with $C$. arvensicola DSM $3695^{\mathrm{T}}$ and C. ginsengisegetis Gsoil $040^{\mathrm{T}}$.
The G+C contents of the DNA of strains JS13-10 $10^{\mathrm{T}}$ and JS16- $4^{\mathrm{T}}$ were 47 and $43 \mathrm{~mol} \%$, respectively. Both strains contained a menaquinone with seven isoprene units (MK7) as the major isoprenoid quinone. The fatty acid profile of strain JS13- $10^{\mathrm{T}}$ was dominated by iso- $\mathrm{C}_{15: 0}(38.2 \%)$, $\mathrm{C}_{16: 1} \omega 5 c(19.6 \%)$ and iso- $\mathrm{C}_{17: 0} 3-\mathrm{OH}(17.2 \%)$ (Table 2). DNA-DNA hybridization tests indicated that the relatedness between strain JS13-10 ${ }^{\mathrm{T}}$ and ' $C$. soli' KACC 12833 was $32 \%$ and that the relatedness values between strain JS16-4 ${ }^{\mathrm{T}}$, C. arvensicola KCTC $2943^{\mathrm{T}}$ and C. ginsengisegetis KACC $12723^{\mathrm{T}}$ were 36 and $30 \%$, respectively.

The phenotypic differences found between strains JS13-10 and $J S 16-4^{\mathrm{T}}$ were in relation to maximum growth temperature, hydrolysis of urea, and in the assimilation, enzymic and fatty acid profiles. Strain JS $13-10^{\mathrm{T}}$ could be differentiated from its closest relative, ' $C$. soli' KACC 12833 , on the basis of growth at $37^{\circ} \mathrm{C}$, differences in the assimilation and enzymic profiles and by variation in fatty acid composition. Strain JS16-4 $4^{\mathrm{T}}$ could be separated from its closest relative, $C$. arvensicola, on the basis of nitrate reduction, growth at $37{ }^{\circ} \mathrm{C}$ and the assimilation, enzymic and fatty acid profiles. In addition to these phenotypic differences, the DNA-DNA hybridization values (which were considerably less than $70 \%$ ) obtained with respect to closely related species indicated that strains JS13-10 and JS16-4 ${ }^{\mathrm{T}}$ represent novel species of the genus Chitinophaga, for which the names Chitinophaga niabensis sp. nov. and Chitinophaga niastensis sp. nov. are proposed, respectively.

\section{Description of Chitinophaga niabensis sp. nov.}

Chitinophaga niabensis [ni.ab.en'sis. N.L. fem. adj. niabensis pertaining to NIAB, the National Institute of Agricultural Biotechnology (Suwon, Republic of Korea), where taxonomic studies were conducted].

Cells are Gram-negative, aerobic, non-motile, rod-shaped, $0.5-0.7 \mu \mathrm{m}$ wide and 1-7 $\mu \mathrm{m}$ long. Oxidase- and catalasepositive. Colonies are yellowish, circular and convex with clear margins. Grows at temperatures between 5 and $40{ }^{\circ} \mathrm{C}$, with optimum growth at $28-30{ }^{\circ} \mathrm{C}$. The $\mathrm{pH}$ range for growth is 6.0-9.0, with an optimum at $\mathrm{pH}$ 7.0. Grows in the absence of $\mathrm{NaCl}$ and in the presence of $2.0 \%(\mathrm{w} / \mathrm{v})$ $\mathrm{NaCl}$, but not with $3.0 \%(\mathrm{w} / \mathrm{v}) \mathrm{NaCl}$. Grows on $\mathrm{R} 2 \mathrm{~A}$, nutrient agar and trypticase soy agar, but not on MacConkey agar. Hydrolyses casein and tyrosine, but not chitin, carboxymethylcellulose, DNA, hypoxanthine, pectin, starch, Tween 80 or xanthine. Other physiological properties are shown in Table 1. The major isoprenoid quinone is MK-7. The major fatty acids $(>10 \%)$ are iso- $\mathrm{C}_{15: 0}, \mathrm{C}_{16: 1} \omega 5 c$ and iso- $\mathrm{C}_{17: 0} 3-\mathrm{OH}$.

The type strain, JS13 $-10^{\mathrm{T}}\left(=\right.$ KACC $\left.12952^{\mathrm{T}}=\mathrm{JCM} 15440^{\mathrm{T}}\right)$, was isolated from soil from Jeju Island, Republic of Korea. The DNA G + C content of the type strain is $47 \mathrm{~mol} \%$ (by HPLC). 
Table 1. Differential phenotypic characteristics of strain $\mathrm{JS} 13-10^{\top}$, strain $\mathrm{JS} 16-4^{\top}$ and other members of the genus Chitinophaga

Strains: 1, JS13-10 ${ }^{\mathrm{T}}$; 2, JS16-4 ${ }^{\mathrm{T}}$; 3, C. arvensicola DSM $3695^{\mathrm{T}}$ and IFO $12650^{\mathrm{T}}$ (Reichenbach, 1989; Kämpfer et al., 2006; Pankratov et al., 2006); 4, C. filiformis DSM 527 ${ }^{\mathrm{T}}$ (Reichenbach, 1989; Kämpfer et al., 2006); 5, C. ginsengisegetis KACC $12723^{\mathrm{T}}$ (Lee et al., 2007); 6, C. ginsengisoli KACC 12724 ${ }^{\mathrm{T}}$ (Lee et al., 2007); 7, C. japonensis DSM $13484^{\mathrm{T}}$ (Fujita et al., 1996; Kämpfer et al., 2006); 8, C. pinensis DSM 2588 ${ }^{\mathrm{T}}$ (Reichenbach, 1989; Kämpfer et al., 2006); 9, C. sancti DSM $784^{\mathrm{T}}$ (Reichenbach, 1989; Kämpfer et al., 2006); 10, C. skermanii CIP 109140 ${ }^{\mathrm{T}}$ (Kämpfer et al., 2006); 11, C. terrae KACC $12755^{\mathrm{T}}$ (Kim \& Jung, 2007); 12, 'C. soli' KACC 12833 (An et al., 2007); 13, KACC 12832 (An et al., 2007). According to the API 20NE test strips, all strains are positive for aesculin hydrolysis, gelatin hydrolysis and $\beta$-galactosidase activity, but are negative for indole production, glucose fermentation and arginine dihydrolase. According to the API 20NE and API ID 32GN test strips, all strains assimilate D-glucose, D-mannose, $N$ acetylglucosamine, maltose, sucrose and melibiose, but do not assimilate D-mannitol, capric acid, adipic acid, trisodium citrate, phenylacetic acid, itaconic acid, suberic acid, sodium malonate, sodium acetate, lactic acid, L-alanine, potassium 5-ketogluconate, glycogen, 3-hydroxybenzoic acid, Dsorbitol, propionic acid, valeric acid, potassium 2-ketogluconate, 3-hydroxybutyric acid or 4-hydroxybenzoic acid. According to the API ZYM test strips, all strains are positive for alkaline phosphatase, leucine arylamidase, valine arylamidase, acid phosphatase, naphthol-AS-BIphosphohydrolase, $\beta$-glucosidase and $N$-acetyl- $\beta$-glucosaminidase, but negative for lipase C14 and $\beta$-glucuronidase. + , Positive; $(+)$, weakly positive; - , negative; ND, not determined.

\begin{tabular}{|c|c|c|c|c|c|c|c|c|c|c|c|c|c|}
\hline Characteristic & 1 & 2 & 3 & 4 & 5 & 6 & 7 & 8 & 9 & 10 & 11 & 12 & 13 \\
\hline Catalase/oxidase & $+1+$ & $+1+$ & $+1+$ & $-1+$ & $-1-$ & $+1+$ & $+/+$ & $+1-$ & $-/ \mathrm{ND}$ & $+1+$ & $+1+$ & $+1+$ & $+1+$ \\
\hline Cell length $(\mu \mathrm{m})$ & $1-7$ & $1-13$ & $1.5-40$ & $30-80$ & $1.1-1.3$ & $1.2-1.6$ & $2-18$ & $<40$ & $2-15$ & $1-2$ & $0.6-0.8$ & $1.0-1.3$ & $0.9-1.4$ \\
\hline $\begin{array}{l}\text { Max. } \mathrm{NaCl}(\% \mathrm{w} / \mathrm{v}) \\
\text { tolerated }\end{array}$ & 2.0 & 2.0 & 3.0 & 0.3 & 2.0 & $<1.0$ & 2.0 & $<2.0$ & 1.0 & $\mathrm{ND}$ & $\mathrm{ND}$ & 1.0 & 3.0 \\
\hline Nitrate reduction $\dagger$ & - & - & $+\ddagger$ & + & - & - & + & + & + & - & + & - & + \\
\hline Urease $\dagger$ & - & $(+)$ & $(+) \ddagger$ & - & $(+)$ & $(+)$ & + & - & - & $(+)$ & + & - & - \\
\hline \multicolumn{14}{|l|}{ Assimilation of: $\dagger$} \\
\hline L-Arabinose & + & - & $+\ddagger$ & + & + & + & + & + & + & - & + & + & + \\
\hline Potassium gluconate & - & - & $-\ddagger$ & - & - & $(+)$ & - & $(+)$ & $(+)$ & $(+)$ & - & - & - \\
\hline Malic acid & - & - & $-\ddagger$ & - & - & - & - & - & - & + & - & - & - \\
\hline Salicin & $(+)$ & + & $+\ddagger$ & $(+)$ & $(+)$ & + & - & + & + & + & + & + & + \\
\hline L-Fucose & $(+)$ & - & $+\ddagger$ & - & + & - & + & $(+)$ & - & $(+)$ & + & $(+)$ & $(+)$ \\
\hline L-Histidine & - & $(+)$ & $(+) \ddagger$ & - & $(+)$ & - & - & - & $(+)$ & $(+)$ & - & $(+)$ & - \\
\hline L-Proline & - & - & $+\ddagger$ & $(+)$ & + & $(+)$ & - & $(+)$ & $(+)$ & + & $(+)$ & $(+)$ & - \\
\hline \multicolumn{14}{|l|}{ Enzyme activities: $\dagger$} \\
\hline Esterase C4 & + & - & $(+) \ddagger$ & + & $(+)$ & $(+)$ & $(+)$ & $(+)$ & $(+)$ & $(+)$ & $(+)$ & $(+)$ & $(+)$ \\
\hline Esterase lipase C8 & + & - & $-\ddagger$ & - & - & - & - & $(+)$ & - & $(+)$ & - & $(+)$ & $(+)$ \\
\hline Cystine arylamidase & $(+)$ & $(+)$ & $(+) \ddagger$ & - & $(+)$ & $(+)$ & $(+)$ & + & $(+)$ & + & + & + & + \\
\hline Trypsin & + & - & $+\ddagger$ & + & + & + & + & + & + & + & + & + & + \\
\hline$\alpha$-Chymotrypsin & + & - & $-\ddagger$ & - & - & - & - & + & - & - & + & + & + \\
\hline$\alpha$-Galactosidase & + & - & $+\ddagger$ & + & + & + & + & + & + & + & + & - & + \\
\hline
\end{tabular}

${ }^{*} \mathrm{GY}$, Golden yellow; Y, yellow; YO, yellow-orange.

$\dagger$ Data from this study.

$\ddagger$ Data for KCTC $2943^{\mathrm{T}}$. 


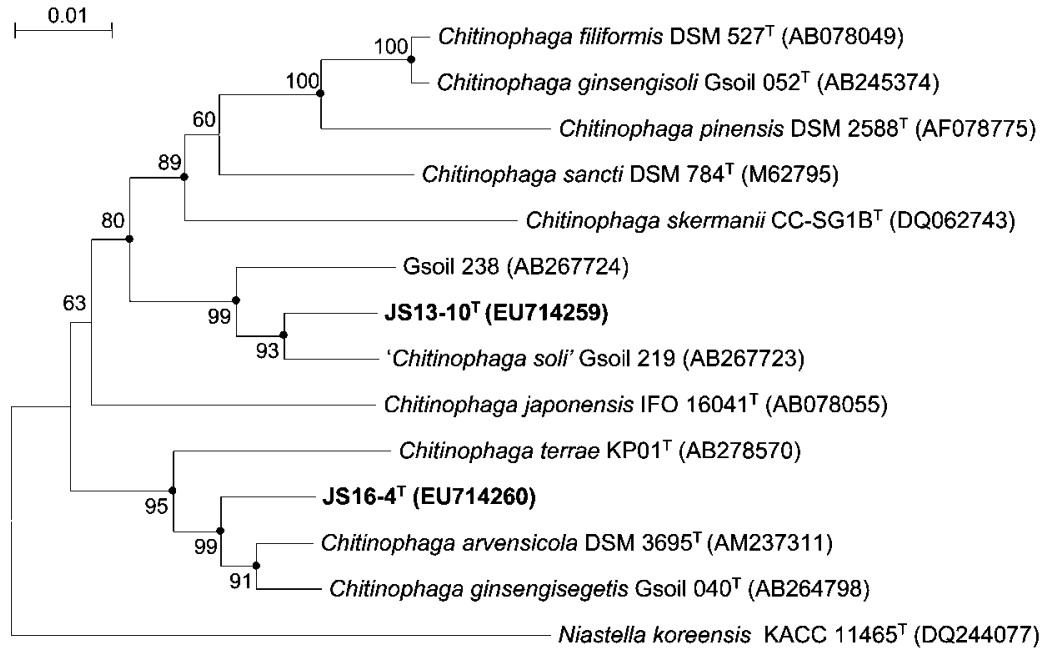

Fig. 1. Neighbour-joining phylogenetic tree, based on 16S rRNA gene sequences, showing the positions of strains $\mathrm{JS} 13-10^{\top}$ and JS16-4 $4^{\top}$. Numbers at nodes indicate bootstrap percentages (based on 1000 resamplings); only values $>50 \%$ are given. Filled circles indicate that the corresponding branches were also recovered in the maximum-parsimony phylogenetic tree. Bar, 0.01 substitutions per nucleotide position.
Description of Chitinophaga niastensis sp. nov.

Chitinophaga niastensis [ni.as.ten'sis. N.L. fem. adj. niastensis pertaining to NIAST, the National Institute of Agricultural Science and Technology (Suwon, Republic of Korea), where taxonomic studies were conducted].
Cells are Gram-negative, aerobic, non-motile, rod-shaped, $0.6-0.7 \mu \mathrm{m}$ wide and $1-13 \mu \mathrm{m}$ long. Oxidase- and catalasepositive. Colonies are yellowish and smeared. Grows at temperatures between 5 and $30{ }^{\circ} \mathrm{C}$, with optimum growth occurring at $28{ }^{\circ} \mathrm{C}$. The $\mathrm{pH}$ range for growth is $5.0-9.0$,

Table 2. Fatty acid compositions of strains $\mathrm{JS} 13-10^{\top}, \mathrm{JS} 16-4^{\top}$ and other strains of the genus Chitinophaga

Strains: 1, JS13-10 ${ }^{\mathrm{T}} ; 2$, JS16-4 ${ }^{\mathrm{T}} ; 3$, C. arvensicola KCTC $2943^{\mathrm{T}} ; 4$, C. filiformis DSM $527^{\mathrm{T}} ; 5$, C. ginsengisegetis KACC $12723^{\mathrm{T}} ; 6$, C. ginsengisoli KACC $12724^{\mathrm{T}} ; 7$, C. japonensis DSM $13484^{\mathrm{T}} ; 8$, C. pinensis DSM $2588^{\mathrm{T}}$; 9, C. sancti DSM $784^{\mathrm{T}} ; 10$, C. skermanii CIP $109140^{\mathrm{T}} ; 11$, C. terrae KACC $12755^{\mathrm{T}}$; 12, 'C. soli' KACC 12833; 13, KACC 12832. All strains were grown at $30{ }^{\circ} \mathrm{C}$ for 2 days.,$-<1.0 \%$ or not detected.

\begin{tabular}{|c|c|c|c|c|c|c|c|c|c|c|c|c|c|}
\hline Fatty acid & 1 & 2 & 3 & 4 & 5 & 6 & 7 & 8 & 9 & 10 & 11 & 12 & 13 \\
\hline $\mathrm{C}_{12: 1}$ AT 11-12 & - & - & - & - & - & - & - & - & 4.0 & - & - & - & - \\
\hline $\mathrm{C}_{14: 0}$ & 1.2 & 1.8 & 1.6 & - & 1.8 & - & - & - & 1.0 & 2.0 & 1.6 & 1.4 & 1.2 \\
\hline anteiso- $\mathrm{C}_{15: 0}$ & - & 1.2 & - & - & - & - & - & - & - & - & - & - & 1.1 \\
\hline iso- $\mathrm{C}_{15: 0}$ & 38.2 & 36.6 & 35.6 & 41.0 & 38.3 & 39.0 & 39.1 & 33.2 & 38.8 & 45.8 & 49.0 & 51.0 & 41.3 \\
\hline iso- $\mathrm{C}_{15: 0} 3-\mathrm{OH}$ & 7.7 & 4.7 & 4.2 & 3.2 & 4.2 & 3.3 & 2.6 & 3.1 & 4.3 & 5.7 & 5.0 & 4.6 & 4.4 \\
\hline$C_{16: 0}$ & 2.8 & 6.5 & 4.3 & 4.0 & 3.4 & 1.6 & 4.4 & 4.1 & 4.6 & 3.8 & 3.4 & 3.1 & 6.8 \\
\hline $\mathrm{C}_{16: 0} 2-\mathrm{OH}$ & - & - & - & - & - & - & 1.8 & - & - & - & - & - & - \\
\hline $\mathrm{C}_{16: 0} 3-\mathrm{OH}$ & 2.0 & 1.4 & 1.9 & - & - & 1.2 & - & 1.0 & - & 2.3 & 1.0 & 1.5 & 1.4 \\
\hline iso- $\mathrm{C}_{16: 0}$ & - & - & - & - & - & - & - & - & - & - & - & - & 1.2 \\
\hline $\mathrm{C}_{16: 1} \omega 5 c$ & 19.6 & 32.5 & 36.1 & 27.9 & 34.2 & 31.7 & 26.0 & 34.7 & 23.9 & 19.0 & 21.3 & 19.1 & 21.6 \\
\hline $\mathrm{C}_{16: 1} \omega 11 c$ & - & - & 2.0 & 2.7 & - & 1.1 & 2.1 & 3.5 & 3.4 & 2.6 & - & - & - \\
\hline $\mathrm{C}_{17: 0} 2-\mathrm{OH}$ & - & - & - & - & - & - & - & - & - & - & - & - & 1.2 \\
\hline $\mathrm{C}_{17: 0} 3-\mathrm{OH}$ & 1.6 & - & - & - & - & - & - & - & - & - & - & 1.2 & - \\
\hline iso- $\mathrm{C}_{17: 0}$ & - & - & - & - & - & - & 1.4 & - & - & - & - & - & - \\
\hline iso- $\mathrm{C}_{17: 0} 3-\mathrm{OH}$ & 17.2 & 9.2 & 8.6 & 7.8 & 8.3 & 9.6 & 11.4 & 11.2 & 7.7 & 9.2 & 6.5 & 10.1 & 11.7 \\
\hline \multicolumn{14}{|c|}{ Unknown fatty acids* } \\
\hline ECL 13.565 & - & 1.7 & 2.0 & 1.3 & 4.5 & 1.6 & 2.1 & - & 2.4 & 1.7 & 1.3 & 2.4 & - \\
\hline ECL 14.959 & - & - & - & - & - & - & - & - & - & - & 1.7 & - & - \\
\hline \multicolumn{14}{|c|}{ Summed features $\dagger$} \\
\hline 3 & 4.4 & 4.4 & 3.7 & 8.0 & 5.3 & 9.1 & 2.1 & 5.5 & 9.9 & 5.6 & 4.2 & 3.5 & 4.7 \\
\hline 4 & - & - & - & - & - & - & 1.4 & - & - & - & - & - & - \\
\hline
\end{tabular}

${ }^{\star}$ ECL, Equivalent chain length.

$\uparrow$ Summed features are groups of two or three fatty acids that cannot be separated by GLC with the MIDI system. Summed feature 3 comprises iso- $\mathrm{C}_{15: 0} 2-\mathrm{OH}$ and/or $\mathrm{C}_{16: 1} \omega 7 \mathrm{c}$. Summed feature 4 comprises iso- $\mathrm{C}_{17: 1} \mathrm{I}$ and/or anteiso- $\mathrm{C}_{17: 1} \mathrm{~B}$. 
with an optimum between $\mathrm{pH} 6.0$ and 7.0. Grows in the absence of $\mathrm{NaCl}$ and in the presence of $2.0 \%(\mathrm{w} / \mathrm{v}) \mathrm{NaCl}$, but not with $3.0 \%(\mathrm{w} / \mathrm{v}) \mathrm{NaCl}$. Grows on R2A, nutrient agar and trypticase soy agar, but not on MacConkey agar. Hydrolyses Tween 80, but not casein, chitin, carboxymethylcellulose, DNA, hypoxanthine, pectin, starch, Tween 80 , tyrosine or xanthine. Other physiological properties are shown in Table 1. The major isoprenoid quinone is MK-7. The major fatty acids $(>10 \%)$ are iso- $\mathrm{C}_{15: 0}$ and $\mathrm{C}_{16: 1} \omega 5 \mathrm{c}$.

The type strain, JS16 $-4^{\mathrm{T}}\left(=\right.$ KACC $\left.12954^{\mathrm{T}}=\mathrm{JCM} 15441^{\mathrm{T}}\right)$, was isolated from soil from Jeju Island, Republic of Korea. The DNA G + C content of the type strain is $43 \mathrm{~mol} \%$ (by HPLC).

\section{Acknowledgements}

This work was supported by a grant (06-4-11-19-1) from the National Institute of Agricultural Biotechnology, Rural Development Administration, Republic of Korea.

\section{References}

An, D.-S., Im, W.-T., Yoon, M.-H., Lee, S.-T. \& Choi, W.-Y. (2007). Chitinophaga soli sp. nov. and Chitinophaga terrae sp. nov., isolated from soil of a ginseng field in Pocheon province, South Korea. $J$ Microbiol Biotechnol 17, 705-711.

Breznak, J. A. \& Costilow, R. N. (1994). Physicochemical factors in growth. In Methods for General and Molecular Bacteriology, pp. 137154. Edited by P. Gerhardt, R. G. E. Murray, W. A. Wood \& N. R. Krieg. Washington, DC: American Society for Microbiology.

Felsenstein, J. (1985). Confidence limits on phylogenies: an approach using the bootstrap. Evolution 39, 783-791.

Fitch, W. M. (1971). Toward defining the course of evolution: minimum change for a specific tree topology. Syst Zool 20, 406-416.

Fujita, T., Okamoto, M., Kosako, Y. \& Okuhura, M. (1996). Flexibacter japonensis sp. nov., a new species that produces a novel inhibitor of human leukocyte elastase isolated from soil. Curr Microbiol 33, 89-93.

Groth, I., Schumann, P., Weiss, N., Martin, K. \& Rainey, F. A. (1996), Agrococcus jenensis gen. nov., sp. nov., a new genus of actinomycetes with diaminobutyric acid in the cell wall. Int J Syst Bacteriol 46, 234-239.

Kämpfer, P., Young, C. C., Sridhar, K. R., Arun, A. B., Lai, W. A., Shen, F. T. \& Rekha, P. D. (2006). Transfer of [Flexibacter] sancti, [Flexibacter] filiformis, [Flexibacter] japonensis and [Cytophaga] arvensicola to the genus Chitinophaga and description of Chitinophaga skermanii sp. nov. Int J Syst Evol Microbiol 56, 2223-2228.
Kim, M. K. \& Jung, H.-Y. (2007). Chitinophaga terrae sp. nov., isolated from soil. Int J Syst Evol Microbiol 57, 1721-1724.

Kimura, M. (1983). The Neutral Theory of Molecular Evolution. Cambridge: Cambridge University Press.

Kumar, S., Tamura, K. \& Nei, M. (2004). MEGA3: integrated software for molecular evolutionary genetics analysis and sequence alignment. Brief Bioinform 5, 150-163.

Kwon, S.-W., Kim, J.-S., Park, I.-C., Yoon, S.-H., Park, D.-H., Lim, C.-K. \& Go, S.-J. (2003). Pseudomonas koreensis sp. nov., Pseudomonas umsongensis sp. nov. and Pseudomonas jinjuensis sp. nov., novel species from farm soils in Korea. Int J Syst Evol Microbiol 53, 21-27.

Lee, H.-G., An, D.-S., Im, W.-T., Liu, Q.-M., Na, J.-R., Cho, D. H., Jin, C. W., Lee, S.-T. \& Yang, D.-C. (2007). Chitinophaga ginsengisegetis sp. nov. and Chitinophaga ginsengisoli sp. nov., isolated from soil of a ginseng field in South Korea. Int J Syst Evol Microbiol 57, 1396-1401.

Mesbah, M., Premachandran, U. \& Whitman, W. B. (1989). Precise measurement of the $\mathrm{G}+\mathrm{C}$ content of deoxyribonucleic acid by highperformance liquid chromatography. Int J Syst Bacteriol 39, 159-167.

Pankratov, T. A., Kulichevskaya, I. S., Liesack, W. \& Dedysh, S. N. (2006). Isolation of aerobic, gliding, xylanolytic and laminarinolytic bacteria from acidic Sphagnum peatlands and emended description of Chitinophaga arvensicola Kämpfer et al. 2006. Int J Syst Evol Microbiol 56, 2761-2764.

Reasoner, D. J. \& Geldreich, E. E. (1985). A new medium for the enumeration and subculture of bacteria from potable water. Appl Environ Microbiol 49, 1-7.

Reichenbach, H. (1989). Genus Flexibacter Soriano 1945, 92, ${ }^{\mathrm{AL}}$ emend. In Bergey's Manual of Systematic Bacteriology, vol. 3, pp. 2061-2071. Edited by J. T. Staley, M. P. Bryant, N. Pfennig \& J. G. Holt. Baltimore: Williams \& Wilkins.

Saitou, N. \& Nei, M. (1987). The neighbor-joining method: a new method for reconstructing phylogenetic trees. Mol Biol Evol 4, 406-425.

Sangkhobol, V. \& Skerman, V. B. D. (1981). Chitinophaga, a new genus of chitinolytic myxobacteria. Int J Syst Bacteriol 31, 285-293.

Seldin, L. \& Dubnau, D. (1985). Deoxyribonucleic acid homology among Bacillus polymyxa, Bacillus macerans, Bacillus azotofixans, and other nitrogen-fixing Bacillus strains. Int J Syst Bacteriol 35, 151-154.

Smibert, R. M. \& Krieg, N. R. (1994). Phenotypic characterization. In Methods for General and Molecular Bacteriology, pp. 607-654. Edited by P. Gerhardt, R. G. E. Murray, W. A. Wood \& N. R. Krieg. Washington, DC: American Society for Microbiology.

Thompson, J. D., Higgins, D. G. \& Gibson, T. J. (1994). CLUSTAL W: improving the sensitivity of progressive multiple sequence alignment through sequence weighting, position-specific gap penalties and weight matrix choice. Nucleic Acids Res 22, 4673-4680. 